\title{
Ergastic Substances (Calcium Oxalate Crystals) in the Leaf of Combretum Loefl. (Combretaceae) Species in Nigeria
}

\author{
Chimezie Ekeke, Ikechukwu 0. Agbagwa \\ Department of Plant Science and Biotechnology, Faculty of Biological Sciences, University of Port Harcourt, \\ Port Harcourt, Nigeria \\ Email: ikechukwu.agbagwa@gmail.com
}

Received 12 May 2014; revised 16 June 2014; accepted 6 July 2014

Copyright (C) 2014 by authors and Scientific Research Publishing Inc. This work is licensed under the Creative Commons Attribution International License (CC BY). http://creativecommons.org/licenses/by/4.0/

(c) (i) Open Access

\begin{abstract}
Leaves of twenty-two (22) species of Combretum in Nigeria were examined for occurrence and distribution of different types and sizes of ergastic substances (calcium oxalate crystals). Fresh and herbarium specimens were used for the study. These specimens were wax embedded, sectioned, mounted and micro-photographed using Leica WILD MPS 52 microscope camera on Leitz Diaplan microscope. Results revealed two types of calcium oxalate crystals-crystal sand and druses. Based on the observed differences in the size of the crystals, three groups of calcium oxalate crystals are reported [large crystals: $180.0-360.0 \mu \mathrm{m}(241 \pm 44.57 \mu \mathrm{m})$, moderate crystals: 90.0 - $144.0 \mu \mathrm{m}(117.0 \pm 20.60 \mu \mathrm{m})$, and small crystals: $18.0-72.0 \mu \mathrm{m}(50.21 \pm 20.42 \mu \mathrm{m})]$. Crystal sand was found only in Combretum sp. 1 but druses of varying sizes predominated amongst species of the genus. Crystals were distributed within the spongy mesophyll, palisade mesophyll, subepidermis adaxial, sub-epidermis abaxial and between the palisade and spongy mesophyll. The findings of this work provide information on the occurrence and distribution of the crystals in the leaf epidermis of these taxa in Nigeria. The formation, occurrence and distribution of the crystal type in the Combretum species constitute dependable taxonomic character especially when combined with other characters.
\end{abstract}

\section{Keywords}

Combretum, Calcium Oxalate Crystals, Crystal Sand, Druses, Mesophyll

\section{Introduction}

Combretum Loefl. belongs to the tribe Combreteae, subfamily Combretoideae in the family Combretaceae [1]. It

How to cite this paper: Ekeke, C. and Agbagwa, I.O. (2014) Ergastic Substances (Calcium Oxalate Crystals) in the Leaf of Combretum Loefl. (Combretaceae) Species in Nigeria. American Journal of Plant Sciences, 5, 2389-2401. 
comprises two subgenera Combretum with eleven sections and Cacoucia [2]. This family is highly heterogeneous and occurs mainly in the tropics, warm temperate and sub-tropical zones of the world. The members of this family are trees or small trees, shrubs or deciduous climbers, sometimes scrambling shrubs with 4- to 5-winged fruits [3] [4]. Forty-nine (49) known species and 8 imperfectly known species have been reported in West Africa with 25 species occurring in Nigeria [4]. The genus has the chromosome number of $2 n=26$ or 39 and the basic chromosome number of $x=13$ [5] [6] and several medicinal values [7]-[17].

Ergastic substances (calcium oxalate crystals) as anatomical structures have been reported to have contributed immensely to plant systematics [18]. Morphologically, there are five main categories of calcium oxalate i.e. raphids, prisms, styloids, druses and crystal sand [19]. In whatever tissue the crystals are found, they most often accumulate within the vacuoles of specialized cells called crystal idioblasts [20]. The number and location of crystal idioblasts within the plant body also vary among taxa. The morphology and distribution of crystals are constant within a species. This indicates that their presence, morphology, and distribution in species are under genetic control [20]-[22]. Although their functional significance in plant development remains unclear, various functions have been attributed to them, including calcium regulation in plant cells [23]-[25], protection against herbivores [26], detoxification of heavy metals or oxalic acid [20], tissue strength, light gathering, and reflection [19] [27].

Among Nigerian species of Combretum, there is limited or no information on the occurrences and distribution of ergastic substances. Therefore, this article described the morphology, distribution and occurrence of calcium oxalate crystals in the leaf lamina of 22 Combretum species (18 existing species and 4 new collections undergoing taxonomic authentication) and their significance in the taxonomic delimitation of members of the genus. The study highlights the significance of crystal size in the taxonomic delimitation of members of the genus.

\section{Materials and Methods}

Plant collection: Field and herbarium studies were carried out in Nigeria (December, 2009 to July, 2012). Live plant specimens were collected from south-south, south-east and western parts of Nigeria. These specimens were taken to Forestry Herbarium Ibadan (FHI) and University of Ibadan Herbarium (UIH) for proper identification. Also, inventory of the specimens in these representative herbaria (University of Ibadan Herbarium, UIH; Forestry Herbarium Ibadan, FHI) were taken. List of Combretum species collected and studied, locality of collection, and name of collector are shown in Table 1.

Anatomical studies: Fresh cut sections of matured midrib of leaves from the specimens were fixed in FAA (formaldehyde:glacial acetic acid:ethanol in the ratio of 1:1:18 parts of $70 \%$ ethanol v/v) for at least 48 hours. These were washed in several changes of distilled water, dehydrated through alcohol series $(30 \%, 50 \%, 70 \%$ and 100\%), 2 hours in each solution and embedded in wax. Sections were cut on a Leitz 1512 rotary microtome at thickness between $20-24 \mathrm{~mm}$. The thin sections selected were de-waxed by passing the specimens through ethanol/chloroform in the ratios 1:3, 1:1 and 3:1 respectively and finally to absolute ethanol and allowed to stay 3 hours in each case; stained with $1 \%$ safranin or alcian blue, and mounted on slide. Photomicrographs of the anatomical sections were taken with a Leitz Diaplan photomicroscope fitted with Leica WILD MPS 52 camera.

\section{Results}

The summary of crystal types, occurrence and distribution in the leaf blade of 22 Combretum species studied are presented in Tables 2-4 and Figure 1 and Figure 2. Two types of calcium oxalate crystals (druses and crystal sand) occurred in the species with druses predominating. Crystal sand was observed only in Combretum sp. 1 (a new collection undergoing taxonomic authentication). Crystals were observed in the spongy mesophyll layer, palisade mesophyll layer, between the palisade and spongy mesophylls, between the palisade mesophyll and the adaxial epidermis (sub-epidermis adaxial) or between the spongy and the abaxial epidermis (sub-epidermis abaxial) as shown in Figure 1 and Figure 2.

\subsection{Distribution of Calcium Oxalate in the Leaf Lamina}

In C. mooreanum and C. paniculatum Table 2, the oxalate crystals were found in the spongy mesophyll, palisade mesophyll, sub-epidermis adaxial and sub-epidermis abaxial layers. However, in C. bracteatum, 
Table 1. Species name, locality, state, name of collector, accession number and date of collection for the Combretum species studied.

\begin{tabular}{|c|c|c|c|}
\hline $\mathbf{S} / \mathbf{N}$ & Species name & Locality/state & Name of collector/accession No./date of collection \\
\hline \multirow{8}{*}{1} & \multirow{8}{*}{ C. bracteatum (Laws) Engl. and Diels. } & Aponum F/R, Akure/Ondo & Odewo and others, FHI 90845, 7/6/1979 \\
\hline & & Atim, Calabar, C/R State & H.D. Onyeachusim, FHI 48155, 13/2/1964 \\
\hline & & Uboma/Orlu Rd, Imo State & Okeke and Macauly, FHI 72161, 25/01/1975 \\
\hline & & Choba, Rivers State & Ekeke, C. \\
\hline & & Ughelli, Delta State & Ekeke, C. \\
\hline & & Umuahia/Ibeku, Abia & J.O. Ariwodo, FHI 81292, 22/01/1975 \\
\hline & & Benin, Edo State & Ekeke, C. \\
\hline & & Awkunanu, Enugu & J.A. Emwiogbon, FHI 72094, 15/11/1973 \\
\hline \multirow{7}{*}{2} & \multirow{7}{*}{$\begin{array}{l}\text { C. collinum Fresen. subsp binderanum } \\
\text { (Kotschy) Okafor }\end{array}$} & New Bussa & Gbile, FHI 91497, 1972 \\
\hline & & Ilorin, Oyo & Oloranfemi and Oguntayo, FHI 88536, 1972 \\
\hline & & Borgu G/R, Kwara & Child, D.S, FHI 30261, 1972 \\
\hline & & Okene, Kogi & Cleyton, 1972 \\
\hline & & Ilorin, Oyo & MacDonald, K.R., FHI 2081 \\
\hline & & Bauchi, Bauchi & Lely, FHI 2095 \\
\hline & & Abuja & Onyeachusim and others, FHI 2679 \\
\hline \multirow{9}{*}{3} & \multirow{9}{*}{$\begin{array}{l}\text { C. collinum Fresen. subsp. hypopilinum } \\
\text { (Diels) Okafor }\end{array}$} & Borgu G/R, Kwara & Child, D.S, FHI 30259, 1972 \\
\hline & & N. Nigeria & J.B. Hall and Daramola, FHI 67472, 1971 \\
\hline & & Enugu, Enugu State & Latilo, FHI 63476, 1971 \\
\hline & & Abuja & Chizea, L.G., FHI 2446, 1975 \\
\hline & & Ago-Are, Oyo state & Olorunfemi and others, FHI 96422, 1975 \\
\hline & & New Bussa & Gbile and others, FHI 91497, 1975 \\
\hline & & Mokwa, Ngier & FHI 9519 \\
\hline & & Awum/Jebba FR, Kwara State & Onyeachusim and others, FHI 3459 \\
\hline & & Abuja & Onyeachusim and others, FHI 2653 \\
\hline \multirow{4}{*}{4} & \multirow{4}{*}{ C. confertum (Laws) Benth } & Bendiga Ayuk, Ikom, C/R state & FHI 2817, 8/12/1950 \\
\hline & & Akamkpa, C/R state & B.O. Daramola, FHI 56413, 19/10/1965 \\
\hline & & Akamkpa, C/R state & Ekeke, C. \\
\hline & & Okobodo, Itu, C/R state & J.O. Ariwodo, FHI 88819, 1/11/1978 \\
\hline \multirow{9}{*}{5} & \multirow{9}{*}{ C. constrictum } & Edge of Orugi Creek, Kabba, Kogi & A.P.D. Jones, 630, 10/2/1943 \\
\hline & & Taylor Creek, Bayelsa & Ekeke, C. \\
\hline & & Oguta Lake, Imo & Ekwuno and others, FHI 96294, 1/9/1981 \\
\hline & & Bangedde River Koton-Kariti, Kogi & J. Peal, FHI 39736, 29/4/1957 \\
\hline & & Taylor Creek, Rivers State & Ekeke, C. \\
\hline & & Taylor Creek, Bayelsa/Rivers & FHI 16524, 10/5/1940 \\
\hline & & Atani, Ogaru, Anambara & J. C. Okafor, FHI 94985, 20/3/1974 \\
\hline & & Ogbaru, C/R State & FHI 94985 \\
\hline & & Ibadan, Oyo & Ekwuno, P, FHI 96294 \\
\hline
\end{tabular}




\section{Continued}

6

$$
\text { C. cuspidatum }
$$

C. glutinosum Perr. Ex DC.
Ikeja, Igboedum, River Ogun, Lagos

$$
\text { Abeokuta, Ogun }
$$

Benin, Bank of Abiala Creek, Edo

Itu Swamp, C/R State

$$
\text { Benin, Edo }
$$

Iyekuselu, Benin, Edo

Ogoja, Ikom, C/R State

Owerri-Onitsha Rd, Owerri, Imo

Uyo, Etip Ediene, Akwa Ibom

$$
\text { Akota, Lagos }
$$

Iva F/R, Awka, Anambara

Manu F/R, Awka, Enugu

Port Harcourt, Rivers

Igume, Igala, Kogi

Ntalakwu, Itu, Abia

Sapoba F/R, Edo

Benin-Auchi Rd 6 20N, 5 40E, Edo

Obiga-Asa, Abia State

Alakahia, River State

Unilag, Campus, Lagos

Zaria, Kaduna

Damaturu, Yobe

Bauchi/Gombe

Kano/Dangora

Yelwa/Sokoto

Ilorin/Borgo, Oyo

Giwa Village, Kaduna

Yankari Game Reserve, Bauchi

Mango, Platuea

Abuja/Bida, Abuja/Niger

Adamawa/Songmubi, Adamawa

Adamawa, Adamawa

Figureau, Platuea

Zamfara, Zamfara

Sokoto, Sokoto

Kwara, Kwara

Oyo F/R, Oyo

Kwara

New Bussa

Awum/Jebba FR, Kwara State

Bauchi

Jankarama, Bayelsa State
C.F.A. Onochie, FHI 26680, 30/12/1952

C.F.A. Onochie, FHI 32443, 16/12/1952

J.R. Charter, FHI 43263, 30/11/60

L.G. Cooper, FHI 36729, 15/10/1957

Onochie, FHI 39274, Nov. 1956

Daramola, FHI 45689, 11/12/1961

P. Ekwuno, FHI 60465, 10/12/1966

Onochie, FHI 35990, 14/1/1957

Okafor and Latilo, FHI 57764, 23/1/1966

J. Opayemi, FHI 68427, 11/12/1971

Emwiogbon and Chiaha, FHI 72224, 19/12/1973

E.T. Akagu, FHI 68056A, 7/3/1974

Jones, 6194, 6/1/1974

Olorumtemi and Ibhanesebhor, FHI 67210, 5/12/1973

Ariwodo and others, FHI 5536, 6/2/1982

Emwiogbon, FHI 63079, 27/0/1971

Jones, FHI 77538, 5/1/1975

Ekeke, C.

Ekeke, C.

J. Opayemi, FHI 7182, 11/12/1971

Peal, FHI 39645, 7/6/1957

Peal, FHI 23370, 24/6/1947

J. R. Charter, FHI 36993, 15/1/1958

Latilo, FHI 27434, 24/4/1950

Onochie, FHI 39659, May, 1957

Onyeachusim, FHI 58166, 4/3/1966

Olorumtemi and Ibhanesebhor, FHI 94453, 11/11/1980 Jones, FHI 68232, 14/3/1973

Ariwodo and others, FHI 2479, 25/7/83

J. Redhead, FHI 57893, 18/2/1966

Macauley and Olorumfemi, FHI 62028, 8/3/1968

Macualey and Olumfemi, FHI 62003, 2/3/1968

J.D. Chapman, FHI 70964, 27/6/1973

Keay, FHI 70598, 29/6/1944

Keay, FHI 16203, 1/5/1946

Harberium/wildlife staff, FHI 91590, 10/10/1979

Keay, FHI 16013, 23/2/1946

Tunde and Oguntayo, FHI 85555, 1972

Gbile and others, FHI 91590, 1975

Onyeachusim and others, FHI 3417

$$
\text { Lely, FHI } 2080
$$

Ekeke, C.

Tunde and Oguntayo, FHI 85555, 1972 


\section{Continued}

10

C. hispidum Laws

11

C. insulare Engl. and Diels

12

C. miranthum

13

C. nigricans var. Elliotii

14

C. paniculatum
Ibadan, Oyo

Abuja/Niger

Kumba/Ebie

Ekiti 7 48N, 5 20E, Ekiti

Ekpoma, Edo State

Ngor-Okpuala, Imo State

Akamkpa, C/R state

Obiga-Asa, Abia State

Choba, Rivers State

Ebonyi/Abakaliki, Ebonyi

Mia Idoanu, Adamawa

Ijaye FR, Oyo

Gambari FR, Ibadan, Oyo

Ibadan North F/R, Oyo

Mokwa, Niger

Ibadan, Oyo

Minna, Niger

Katsina, Kastina

Ilero/Oyo, Oyo

Yankari game Reserve, Bauchi

Pategi/Kwara

Shasha F/R Ife, Ogun

Lokoja, Kogi

Zambufu, Kwara

Odoba/Otukpo, Benue

Daddin, Kowa, Gombe

Okene, Kogi

Iseyin, Oyo state

Omo F/R, Ogun

Manu F/R, Awka, Anambara

Betem, Akamkpa, C/R state

Ogbogo, Rivers State

Kaima, Bayelsa State

Ijaye FR, Oyo

Oyo F/R, Oyo state

Oshun River FR, Oyo

Sapoba, Edo State

Ijebu-Ode, Ogun
Samuel, et al., FHI 32315, 25/1/1972

Latilo, FHI 99283, 3/2/1981

Keay, FHI 37386, 26/1/1956

Jones, FHI 77524, 20/1/1975

Ekeke, C.

Ekeke, C.

Ekeke, C.

Ekeke, C.

Ekeke, C.

Okafor and Emwiogbon, FHI 66030, 27/2/1973

Latilo, FHI 34469, 12/2/1955

Tunde and Oguntayo, FHI 32315, 1972

Chizea, L.G., 1975

Chizea, L.G., FHI 23971, 23/02/50

Olorunfemi and others, FHI 92129, 1975

Lowe, J., FHI2181

Onyeachusim and others, FHI 2655

MacGregor W.D., FHI 2085

Latilo, FHI 58407, 23/3/1966

C. Geerling, FHI 38395, 22/10/1970

Eimujeze and Oguntayo, FHI 72829, 19/10/1974

Latilo, FHI 67531, 20/9/1973

Gbeli, et al., FHI 64202, 20/9/1971

Eimujeze and Oguntayo, FHI 71501, 16/10/1974

Daramola, et al., FHI 5289, 16/6/1978

Wit, et al., FHI 65053, 3/5/1972

Cleyton, 1972

Olorunfemi and others, FHI 96446, 1975

H.D. Onyeachusim, FHI 7622, Jan. 1977

J.A. Emwiogbon, FHI 64000, 17/3/1972

J.O. Ariwodo, 28/01/1977

Ekeke, C.

Ekeke, C.

Tunde and Oguntayo, FHI 32173, 1972

Olorunfemi and others, FHI 92640, 1975

Onyeachusim and others, FHI 2087

Onyeachusim and others

J.D. Kennedy, FHI 2087 


\section{Continued}

15

C. platypterum

16

17

C. zenkeri

18

19

20

21

22

C. racemosum
Ikom, C/R State

Oshun-Ijesa-Ilumoba Rd, Osun

Umuelechi-Asa, Abia Stae

Anambara

Sapele, Delta State

Obinze, Imo State

Atia Mkpat, Akwa Ibom State

Enugu-Nsuka Rd

Sapoba, Edo State

Akilla, W. Nig

Ikom, C/R State

Udi Ngwo, Enugu

Okene

N. Nig Wai Ed

Umuelechi-Asa, Abia Stae

Choba, Rivers State

Obinze, Imo State

Bayelsa

Ejigbo, Oyo

Obatedo, W, Nig

Ogun State

Obudu, C/R State

Udi Ngwo, Enugu

Abeokuta, Ogun

Obudu, C/R State

Iseyi, Oyo state

Abeokuta, Ogun

Ngor-Okpuala, Imo State

Ukanufong, Akwa Ibom State

Combretum sp. 1

Combretum sp. 2.

Combretum sp. 3

Combretum sp. 4

C. lamprocarpum Diels.
Atia Mkpat, Akwa Ibom

Ogbiombiri, Bayelsa

Elele-Owerri Rd, Rivers

Mggirichi-Owerri Rd, Imo

Daddin, Kowa, Gombe
Tunde and Oguntayo, FHI 86153, 1972

Olorunfemi, J.O., FHI 91915, 1975

Ekeke, C.

Ekeke, C.

Ekeke, C.

Ekeke, C.

Ekeke, C.

Onyeachusim and others, FHI 2878

Onyeachusim and others

Onyeachusim and others

Latilo, FHI 31852

257

Cleyton, 1972

Lowe, J., FHI 93218

Ekeke, C.

Ekeke, C.

Ekeke, C.

Ekeke, C.

Daramola and others, FHI 4953

Olorunfemi and others, FHI 4021

Onyeachusim and others, FHI 2090

Savory and Keay, FHI 25274

Jones, A.P.D, 260

J.D. Kennedy, FHI 2090

Savory and Keay, FHI 25128

Olorunfemi and others, FHI 96441, 1975

A.F. Ross, FHI 2097

Ekeke, C.

Ekeke, C.

Ekeke and others, 019, 24/10/11

Ekeke and others, 022, 24/12/11

Ekeke, C., 020, 24/11/11

Ekeke, C., 021, 24/11/11

Wit, et al., FHI 65054, 3/5/1975. 
Table 2. Crystal type and distribution in the leaf lamina of the Combretum species.

\begin{tabular}{|c|c|c|c|c|c|c|c|c|}
\hline \multirow{2}{*}{$\mathbf{S} / \mathbf{N}$} & \multirow{2}{*}{ Species name } & \multicolumn{2}{|c|}{ Sub-epidermis } & \multicolumn{2}{|c|}{ Mesophyll } & \multicolumn{2}{|c|}{ Crystal type } & \multirow{2}{*}{ Group } \\
\hline & & Adaxial & Abaxial & Spongy & Palisade & Druse & Sand & \\
\hline 1 & C. mooreanum Exell. & + & + & + & + & + & - & A \\
\hline 2 & C. paniculatum Vent & + & + & + & + & + & - & A \\
\hline 3 & $\begin{array}{l}\text { C. bracteatum (Laws.) Engl. } \\
\text { and Diels. }\end{array}$ & - & + & + & + & + & - & B \\
\hline 4 & $\begin{array}{l}\text { C. collinum subsp. binderianum } \\
\text { (Diels.) Okafor }\end{array}$ & - & + & + & + & + & - & B \\
\hline 5 & C. micranthum G. Don. & - & + & + & + & + & - & B \\
\hline 6 & $\begin{array}{l}\text { C. platypterum (Welw.) Hutch. } \\
\text { and Dalz. }\end{array}$ & - & + & + & + & + & - & B \\
\hline 7 & $\begin{array}{l}\text { C. collinum Fresen. subsp. } \\
\text { hypopilinum (Diels.) Okafor }\end{array}$ & - & - & + & + & + & - & $\mathrm{C}$ \\
\hline 8 & C. cuspitatum Planch ex Benth. & - & - & + & + & + & - & $\mathrm{C}$ \\
\hline 9 & C. glutinosum Perr. Ex DC. & - & - & + & + & + & - & $\mathrm{C}$ \\
\hline 10 & C. lamprocarpum Diels & - & - & + & + & + & - & $\mathrm{C}$ \\
\hline 11 & C. sordidum Exell. & - & - & + & + & + & - & $\mathrm{C}$ \\
\hline 12 & C. zenkeri Engl. and Diels. & - & - & + & + & + & - & $\mathrm{C}$ \\
\hline 13 & Combretum sp. 4 & - & - & + & + & + & - & $\mathrm{C}$ \\
\hline 14 & C. confertum Laws & - & + & + & - & + & - & $\mathrm{D}$ \\
\hline 15 & C. constrictum (Benth.) Laws & - & + & + & - & + & - & $\mathrm{D}$ \\
\hline 16 & C. insulare Engl. and Diels. & - & + & + & - & + & - & $\mathrm{D}$ \\
\hline 17 & C. dolichopetalum Engl. and Diels. & + & - & - & + & + & - & $\mathrm{E}$ \\
\hline 18 & Combretum sp. 2 & - & + & - & + & + & - & $\mathrm{F}$ \\
\hline 19 & C. hispidum Laws & - & - & + & - & + & - & G \\
\hline 20 & C. racemosum P. Beauv. & - & - & + & - & + & - & G \\
\hline 21 & Combretum sp. 3 & - & - & + & - & + & - & G \\
\hline 22 & Combretum sp. 1 & - & - & + & + & - & + & $\mathrm{H}$ \\
\hline
\end{tabular}

+: present, - : absent.

Table 3. Summary of crystal sizes in the leaf lamina of the Combretum species.

\begin{tabular}{ccccc}
\hline Crystal size & Range $(\boldsymbol{\mu m})$ & Mean & STD & Mean \pm STD \\
\hline Large (L) & $180-360$ & 241.41 & 44.57 & $241.41 \pm 44.57$ \\
Moderate (M) & $90.0-144.0$ & 117 & 20.6 & $117.0 \pm 20.6$ \\
Small (S) & $18.0-72.0$ & 50.21 & 20.42 & $50.21 \pm 20.42$ \\
\hline
\end{tabular}

C. micranthum and C. platypterum it was found in the spongy mesophyll, palisade mesophyll and sub-epidermis abaxial while in C. cuspidatum, C. glutinosum, C. lamprocarpum and C. zenkeri, it occurred in the palisade and spongy mesophylls. The crystal was found in the spongy mesophyll and sub-epidermis abaxial tissues in $C$. confertum, C. constrictum and $C$. insulare. On the other hand, in C. collinum subsp. binderanum the crystal occurred in sub-epidermis adaxial and sub-epidermis abaxial layers while it was observed only in the sub-epidermis layer in $C$. collinum subsp. hypopilinum. The occurrence of the crystal in the other taxa studied include: $C$. dolichopetalum (palisade mesophyll and sub-epidermis adaxial layers), Combretum sp. 2 (palisade mesophyll 
Table 4. Distribution of different sizes of calcium oxalate in the leaf lamina of the Combretum species.

\begin{tabular}{|c|c|c|c|c|c|c|}
\hline \multirow{2}{*}{$\mathrm{S} / \mathrm{N}$} & \multirow{2}{*}{ Species name } & \multicolumn{2}{|c|}{ Sub-epidermis } & \multicolumn{2}{|c|}{ Mesophyll } & \multirow{2}{*}{$\begin{array}{l}\text { Between palisade and } \\
\text { spongy mesophyll }\end{array}$} \\
\hline & & Adaxial & Abaxial & Spongy & Palisade & \\
\hline 1 & C. mooreanum Exell. & - & - & $\mathrm{S}$ & S & $\mathrm{L}$ \\
\hline 2 & C. paniculatum Vent & $\mathrm{L}$ & - & - & - & - \\
\hline 3 & C. bracteatum (Laws.) Engl. and Diels. & - & - & - & - & M \\
\hline 4 & $\begin{array}{l}\text { C. collinum subsp. binderianum } \\
\text { (Diels.) Okafor }\end{array}$ & - & - & M & $\mathrm{L}$ & - \\
\hline 5 & C. micranthum G. Don. & - & - & - & - & $\mathrm{L}$ \\
\hline 6 & C. platypterum (Welw.) Hutch. and Dalz. & - & - & M & - & - \\
\hline 7 & $\begin{array}{l}\text { C. collinum Fresen. subsp. hypopilinum } \\
\text { (Diels.) Okafor }\end{array}$ & - & - & - & - & $\mathrm{L}$ \\
\hline 8 & C. cuspitatum Planch ex Benth. & - & - & - & - & $\mathrm{L}$ \\
\hline 9 & C. glutinosum Perr. ex DC. & - & - & - & $\mathrm{L}$ & - \\
\hline 10 & C. lamprocarpum Diels & - & - & - & - & M \\
\hline 11 & C. sordidum Exell. & - & - & - & $\mathrm{L}$ & - \\
\hline 12 & C. zenkeri Engl. and Diels. & - & - & - & - & M \\
\hline 13 & Combretum sp. 4 & - & - & M & M & M \\
\hline 14 & Combretum sp. 1 & & & S & S & \\
\hline 15 & C. confertum Laws & - & M & - & - & - \\
\hline 16 & C. constrictum (Benth.) Laws & - & M & - & - & - \\
\hline 17 & C. insulare Engl. and Diels. & - & - & $\mathrm{L}$ & - & - \\
\hline 18 & C. dolichopetalum Engl. and Diels. & $\mathrm{L}$ & - & - & - & $\mathrm{L}$ \\
\hline 19 & Combretum sp. 2 & - & - & M & - & - \\
\hline 20 & C. hispidum Laws & - & - & - & $\mathrm{L}$ & $\mathrm{L}$ \\
\hline 21 & C. racemosum P. Beauv. & - & - & M & - & - \\
\hline 22 & Combretum sp. 3 & - & - & M & M & M \\
\hline
\end{tabular}

-: absent; L: large crystal (180 - $360 \mu \mathrm{m})$, M: moderate crystal (90 - $144 \mu \mathrm{m})$; S: small crystal (18 - $72 \mu \mathrm{m})$.

and sub-epidermis abaxial layers), C. zenkeri and Combretum sp. 3 (spongy mesophyll layer only).

\subsection{Calcium Oxalate Crystals Based on Sizes}

Based on sizes, the calcium oxalate crystals found in the species were grouped into three namely (Table 3): large crystals 180.0 - $360.0 \mu \mathrm{m}(241 \pm 44.57 \mu \mathrm{m})$, moderate crystals 90.0 - $144.0 \mu \mathrm{m}(117.0 \pm 20.60 \mu \mathrm{m})$ and small crystals 18.0 - $72.0 \mu \mathrm{m}(50.21 \pm 20.42 \mu \mathrm{m})$ (Table 3 and Table 4).

\section{Discussion}

Morphology, occurrence, distribution and sizes of crystals among plant species have been known to have enormous taxonomic value. The application of this character in the systematics of plant species have been emphasized by different authors [28]-[31]. Jordaan, et al. [32] reported the presence of large druses of calcium oxalate in sub-epidermal tissue of $C$. mossambicense. However, there is no known published work on the calcium oxalate crystals in Combretaceae from Nigeria. In this present study, two types of calcium oxalate crystals 

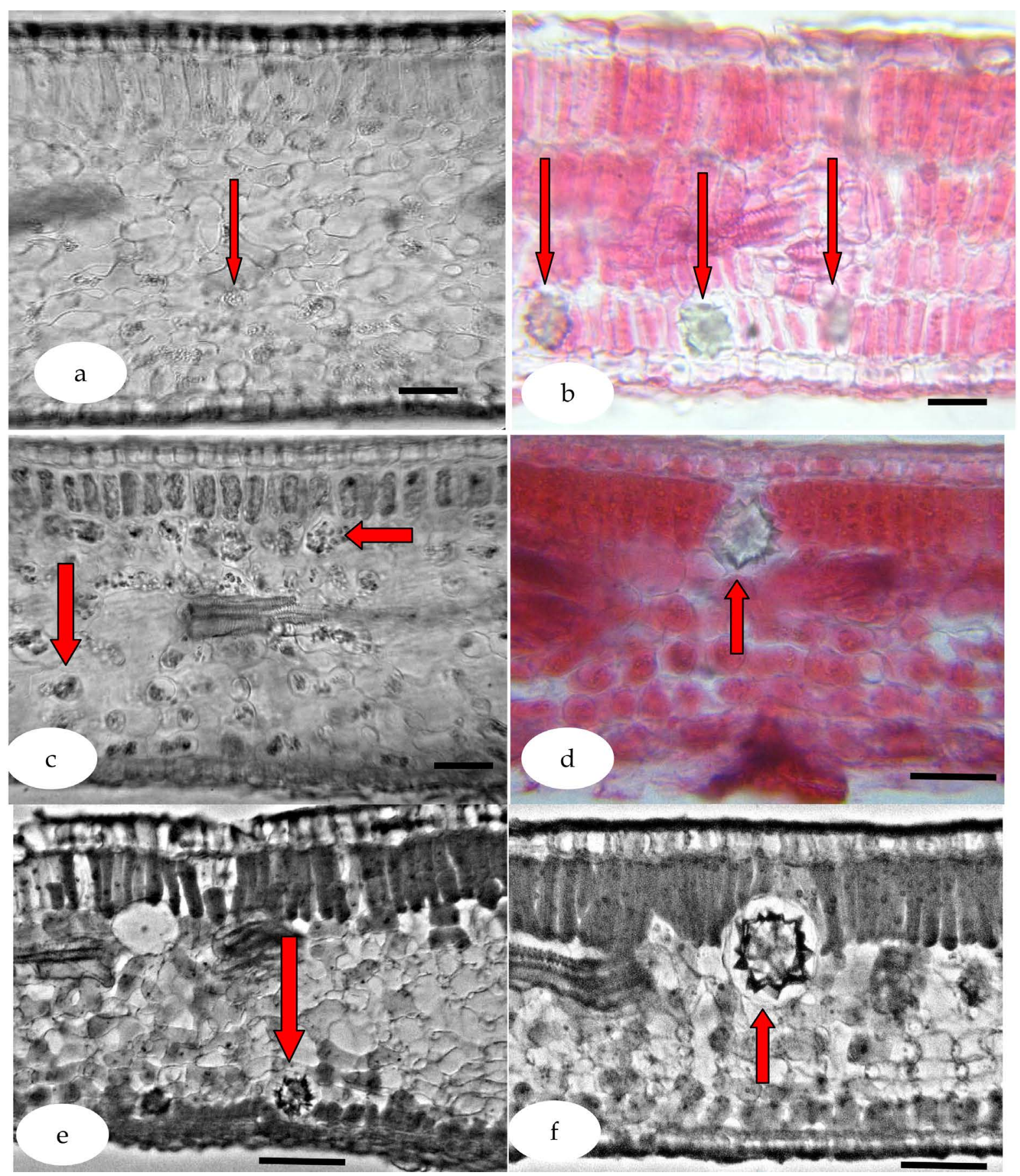

Figure 1. (a)-(f) Leaf lamina showing calcium oxalate crystal distribution: (a) Combretum sp. 1 (arrow shows crystal sand), bar $=116 \mu \mathrm{m}$; (b) C. constrictum (arrows show druse crystals at subepidermis abaxial surface), bar = $120 \mu \mathrm{m}$; (c) C. mooreanum (arrows show oxalate crystals in the spongy mesophyll), bar $=118 \mu \mathrm{m}$; (d) C. glutinosum (arrow shows large druse crystal in the palisade mesophyll), bar $=220 \mu \mathrm{m}$; (e) C. micranthum (arrow shows druse crystal in subepidermis abaxial surface), bar = $240 \mu \mathrm{m}$; (f) Arrow shows large druse crystal between spongy and palisade mesophylls), bar $=242 \mu \mathrm{m}$.

were identified based on their morphology (crystal sand and druses). Crystal sand occurred only in Combertum sp. 1 while druses were predominant and observed in all other species. Occurrence of crystal sand in Combretum sp. 1 remarkably distinguished it from other species. Furthermore, in C. mooreanum and C. paniculatum, crystals were observed in the spongy mesophyll, palisade mesophyll, sub-epidermis adaxial and sub-epidermis 


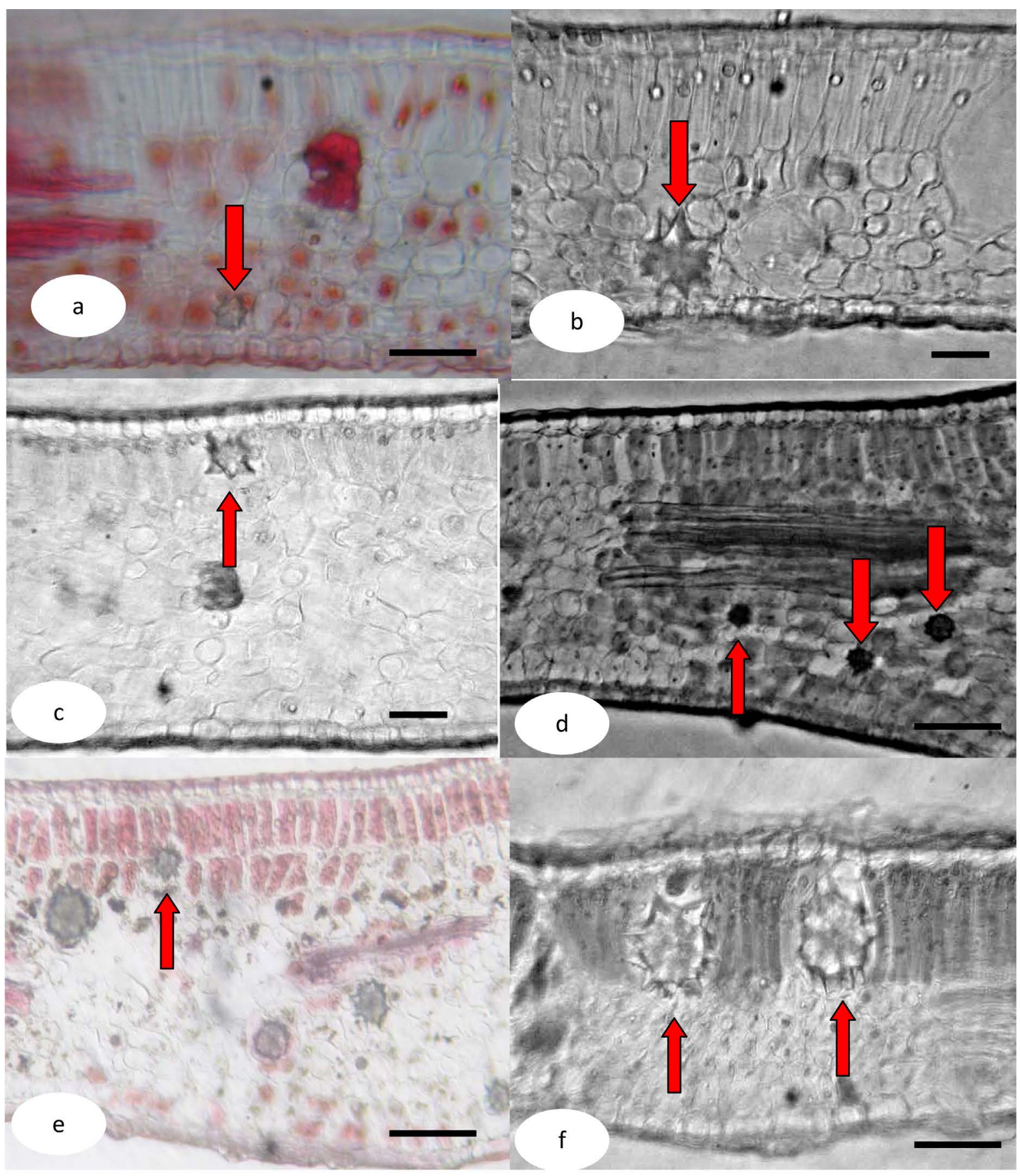

Figure 2. (a)-(f) Leaf lamina showing calcium oxalate crystal distribution: (a) Combretum sp. 2 (arrows show moderate druse crystal in subepidermis abaxial), bar $=240 \mu \mathrm{m}$; (b) C. paniculatum (arrow shows large druse crystal in subepidermis abaxial), bar = $120 \mu \mathrm{m}$; (c) C. paniculatum (arrow shows druse crystal in subepidermis adaxial), bar = $118 \mu \mathrm{m}$; $(\mathrm{d}) C$. platypterum (arrows show small druses in spongy mesophyll), bar $=236 \mu \mathrm{m}$; (e) C. racemosum (arrow shows druse crystal in palisade mesophyll). (f) C. zenkeri (arrows show large druse crystals sandwished in spongy mesophyll), bar $=240 \mu \mathrm{m}$.

abaxial layers but the crystals in C. bracteatum, C. micranthum and C. platypterum, which varied in sizes, occurred in the spongy mesophyll, palisade mesophyll and sub-epidermis abaxial. In C. cuspidatum, C. glutinosum, C. lamprocarpum and C. zenkeri, the crystals occurred in the palisade and spongy mesophllys. The crystals were found in the spongy mesophyll and sub-epidermis abaxial tissues in C. confertum, C. constrictum and $C$. insu- 
lare. On the other hand, in C. collinum subsp. binderianum the crystals occurred in sub-epidermis adaxial and sub-epidermis abaxial layers while it was observed between the spongy and palisade mesophyll in C. collinum subsp. hypopilinum. The occurrence, distribution and sizes of the crystals in the leaf blade of other taxa are shown in Table 2 and Table 4. The pattern of occurrence and distribution of these crystals in the leaf lamina of the Combretum species on one hand is an indication of the similarity (where inter-species crystal occurrence and distribution are similar) and on the other hand, differences (where otherwise) within the genus. Based on the similarity of occurrence and distribution of crystals in the sub-epidermal and mesophyll layers of the leaf, the 22 species of Combretum in this study have been separated into seven groups A-G (Table 2).

It is worthy to note that crystal distribution have been useful taxonomic tool in other angiosperm families. Their occurrence, distribution and systematic importance in some angiosperm families are well documented [28] [30] [31]. In their work, Lersten and Horner [28] showed that in Fagaceae and Nothofagaceae, some species of the sub-family Castaneoideae have crystals occurring in their veins while others lack this feature. In a similar study, Sandra and Julio [31] employed the distribution of the crystals on the leaf blade of Salacioideae to improve the classification of the species where calcium oxalate crystals occurrence and distribution differ from species to species. Also in Asparagales, raphid crystals were completely absent [33] while in subfamilies Opuntioideae and Cereoideae (Cactaceae) different morphological types of crystals have been recorded [18]. Similar studies of the genus Peperomia (Piperaceae) revealed three types of crystal forms with species specific arrangements to certain tissues [34]. In the petiole of two Lantana species, Passos, et al., [35] showed that the vascular system organization pattern and the secretory idioblasts (visualized only in the cortex of L. camara) are good distinctive characteristics.

The distribution and variation in sizes of crystals among these Combretum species were found to vary from species to species. Among the different species studied, the position of the different sizes of crystals in the lamina varied from one species to another. Apart from the presence of these different sizes of calcium oxalate in the different tissues of the lamina, the combination of the different sizes varied from one species to another. Based on this the species could be divided into five major groups (Table 4). The first group is distinct from other species studied and contained only Combretum sp. 1 which has only small crystals $(18.0-72.0 \mu \mathrm{m} ; 50.21 \pm$ $20.42 \mu \mathrm{m}$ ). These crystals were found in palisade and spongy mesophylls. The second group has species with only moderate size of calcium oxalate $(90.0-144.0 \mu \mathrm{m} ; 117.0 \pm 20.60 \mu \mathrm{m})$ but occurring in different tissues in the lamina. Within this group, C. bracteatum, C. zenkeri and C. lamprocarpum have crystals only between the palisade and spongy mesophylls; however, in Combretum sp. 3 and Combretum sp. 4, the moderate crystals were found in the palisade, spongy and between the palisade and spongy mesophylls. Furthermore, C. platypterum, C. racemosum and Combretum sp. 2 have moderate crystals only in the spongy mesophyll while in C. confertum and C. constrictum the moderate crystals were found strictly in the sub-epidermis abaxial layer. Third group have large calcium oxalate crystals $(180.0-360.0 \mu \mathrm{m} ; 241 \pm 44.57 \mu \mathrm{m})$ in different tissues in the leaf lamina. C. cuspidatum and C. hispidum have the large crystals in palisade, spongy and between the palisade and spongy mesophylls, $C$. insulare has the large crystals in the sub-epidermis adaxial and spongy mesophyll, $C$. glutinosum and C. sordidum have the large crystal only in the palisade while in C. paniculatum, they were found only in the sub-epidermis adaxial. On the other hand, in C. micranthum and C. collinum subsp. hyppopilinum, large oxalate crystals were found in the palisade and spongy mesophyll. The fourth group has both small and large calcium oxalate crystals in different positions in the lamina. C. mooreanum a member of this group has the small crystals in the palisade and spongy mesophyll while the large ones are found in-between the palisade and spongy mesophyll. On the other hand, C. dolichopetalum differed from C. mooreanum in that the large crystals are found in the sub-epidermis adaxial. Finally, the fifth group has only one species and this species has large and moderate crystals. The moderate crystals were in spongy mesophyll while large crystals were found in the palisade mesophyll. Though these oxalate crystals may occur in the same tissue, their sizes varied among the species, and these size variations are consistent. These results are however in tandem with Lersten and Horner [28] who reported predominant occurrence of large calcium oxalate crystals in the palisade parenchyma of some angiosperm.

\section{Conclusion}

The findings of this work showed that these characters (occurrence, distribution and sizes) of calcium oxalate in the leaf of the Combretum are valuable for taxonomic delimitation of members of the genus. These therefore 
constitute dependable diagnostic character especially when combined with other characters for the systematics of this genus. The findings of the study also agree with previous studies which showed that crystals as taxonomic character have phylogenetic significance [30] [36]-[39].

\section{References}

[1] Excel, W. (1931) The Genera of Combretaceae. Journal of Botany (London), 69, 113-128.

[2] Carr, J.D. (1988) Combretaceae in Southern Africa. The Tree Society of Southern Africa, Johannesburg.

[3] Keay, R.W.J. (1989) Trees of Nigeria. Clarendon Press, Oxford.

[4] Hutchinson, J. and Dalziel, J.M. (1954) Flora of West Tropical Africa. Vol. 1, Part 1, Crown Agents for Oversea Governments and Administrations, London.

[5] Ekeke, C., Agbagwa, I. and Okoli, B. (2013) Mitotic Study on Combretum Loefl. from Nigeria. American Journal of Plant Sciences, 4, 508-511. http://dx.doi.org/10.4236/ajps.2013.43064

[6] Brighton, A. and Wickens, G.E. (1976) Some Chromosome Counts in the Genus Combretum (Combretaceae). Kew Bulletin, 31, 5-8. http://dx.doi.org/10.2307/4108991

[7] Fyhrquist, P., Mwasumbi, L., Hæggström, C.A., Vuorela, H., Hiltunen, R. and Vuorela, P. (2002) Ethnobotanical and Antimicrobial Investigation on Some Species of Terminalia and Combretum (Combretaceae) Growing in Tanzania. Journal of Ethnopharmacology, 79, 169-177. http://dx.doi.org/10.1016/S0378-8741(01)00375-0

[8] Baba-Moussa, F., Akpagana, K. and Bouchet, P. (1999) Antifungal Activities of Seven West African Combretaceae Used in Traditional Medicine. Journal of Ethnopharmacology, 66, 335-338. http://dx.doi.org/10.1016/S0378-8741(98)00184-6

[9] Simon, G.J., Dewelle, O., Nacoulma, P., Guissou, R., Kiss, D.D. and Braekman, J.C. (2003) Cytotoxic Pentacyclic Triterpenes from Combretum nigricans. Fitoterapia, 74, 339-344. http://dx.doi.org/10.1016/S0367-326X(03)00046-7

[10] Batawila, K., Kokou, K., Koumaglo, K., Gbéassor, M., de Foucault, B., Bouchet, P. and Akpagana, K. (2005) Antifungal Activities of Five Combretaceae Used in Togolese Traditional Medicine. Fitoterapia, 76, 264-268. http://dx.doi.org/10.1016/j.fitote.2004.12.007

[11] Martini, N.D., Katerere, D.R.P. and Eloff, J.N. (2004) Biological Activity of Five Antibacterial Flavonoids from Combretum erythrophyllum (Combretaceae). Journal of Ethnopharmacology, 93, 207-212. http://dx.doi.org/10.1016/j.jep.2004.02.030

[12] Martini, N.D., Katerere, D.R.P. and Eloff, J.N. (2004) Antibacterial Flavonoids Isolated from Combretum erythrophyllum (Burch) Sond (Combretaceae). South African Journal of Botany, 70, 310-312.

[13] Karou, D., Dicko, M.H., Simpore, J. and Traore, A.S. (2005) Antioxidant and Antibacterial Activities of Polyphenols from Ethnomedicinal Plants of Burkina Faso. African Journal Biotechnology, 4, 823-828.

[14] Cowan, M.M. (1999) Plant Products as Antimicrobial Agents. Clinical Microbiology Reviews, 12, 564-582.

[15] Pettit, G.R., Singh, S.B., Niven, M.L., Hamel, E. and Schmidt, J.M. (1987) Isolation Structure and Synthesis of Combretastatins A-1 and B-1 Potent New Inhibitors of Microtubule Assembly Derived from Combretum caffrum. Journal of Natural Products, 50, 119-131. http://dx.doi.org/10.1021/np50049a016

[16] Kloucek, P., Polesny, Z., Svobodova, B., Vlkova, E. and Kokoska, L. (2005) Antibacterial Screening of Some Peruvian Medicinal Plants Used in Callería District. Journal of Ethnopharmacology, 99, 309-312. http://dx.doi.org/10.1016/j.jep.2005.01.062

[17] Watson, L. and Dallwitz, M.J. (2009) Combretum bracteosum Extracts as Eco-Friendly Corrosion Inhibitor for Mild Steel Acidic Medium. Pigment Technology, 38, 236-241. http://dx.doi.org/10.1108/03699420910973323

[18] Monje, P.V. and Baran, E.J. (2002) Characterization of Calcium Oxalates Generated as Biominerals Incacti. Plant Physiology, 128, 707-713. http://dx.doi.org/10.1104/pp.010630

[19] Franceschi, V.R. and Horner, H.T. (1980) Calcium Oxalate Crystals in Plants. Botany Review, 46, 361-427. http://dx.doi.org/10.1007/BF02860532

[20] Franceschi, V.R. and Nakata, P.A. (2005) Calcium Oxalate in Plants: Formation and Function. Annual Review of Plant Biology, 5, 641-671.

[21] Nakata, P.A. and McConn, M.M. (2000) Isolation of Medicago truncatula Mutants Defective in Calcium Oxalate Crystal Formation. Plant Physiology, 124, 1097-1104. http://dx.doi.org/10.1104/pp.124.3.1097

[22] Ilarslan, H., Palmer, R.G. and Horner, H.T. (2001) Calcium Oxalate Crystals in Developing Seeds of Soybean. Annals of Botany, 88, 243-257. http://dx.doi.org/10.1006/anbo.2001.1453

[23] Franceschi, V.R. (1989) Calcium Oxalate Formation Is a Rapid and Reversible Process in Lemna minor L. Protoplas- 
ma, 148, 130-137. http://dx.doi.org/10.1007/BF02079332

[24] Kostman, T.A. and Franceschi, V.R. (2000) Cell and Calcium Oxalate Crystal Growth Is Coordinated to Achieve High-Capacity Calcium Regulation in Plants. Protoplasma, 214, 166-179. http://dx.doi.org/10.1007/BF01279061

[25] Volk, G.M., Lynch-Holm, V., Kostman, T.A. and Franceschi, V.R. (2002) The Role of Druse and Raphide Calcium Oxalate Crystals in Tissue Calcium Regulation in Pistia stratiotes Leaves. Plant Biology, 4, 34-45. http://dx.doi.org/10.1055/s-2002-20434

[26] Molano-Flores, B. (2001) Herbivory and Calcium Concentrations Affect Calcium Oxalate Crystal Formation in Leaves of Sida (Malvaceae). Annals of Botany, 88, 387-391. http://dx.doi.org/10.1006/anbo.2001.1492

[27] Kuo-Huang, L.-L., Ku, M.S.B. and Franceschi, V.R. (2007) Correlations between Calcium Oxalate Crystals and Photosynthetic Activities in Palisade Cells of Shade Adapted Peperomia glabella. Botany, 48, 155-164.

[28] Lersten, N.R. and Horner, H.T. (2008) Crystal Macro-Patterns in Leaves of Fagaceae and Nothofagaceae: A Comparative Study. Plant Systematics and Evolution, 271, 239-253. http://dx.doi.org/10.1007/s00606-007-0620-4

[29] Lersten, N.R. and Curtis, J.D. (1994) Leaf Anatomy in Caesalpinia and Hoffmannseggia (Leguminosae, Caesalpiniodeae) with Emphasis on Secretory Structures. Plant Systematics and Evolution, 192, 231-255. http://dx.doi.org/10.1007/BF00986254

[30] Zona, S. (2004) Raphides in Palm Embryos and Their Systematic Distribution. Annals of Botany, 93, 415-421. http://dx.doi.org/10.1093/aob/mch060

[31] Gomes, S.M.A. and Lombardi, J.A. (2010) Leaf Anatomy as a Contribution to the Taxonomy of Salacioideae N. Halle ex Thorne and Revael (Celastraceae). Plant Systematics and Evolution, 289, 13-33. http://dx.doi.org/10.1007/s00606-010-0328-8

[32] Jordaan, M., van Wyk, A.E. and Maurin, O. (2011) Generic Status of Quisqualis (Combretaceae), with Notes on the Taxonomy and Distribution of Q. parviflora. Bothalia, 41, 161-169. http://dx.doi.org/10.4102/abc.v41i1.37

[33] Prychid, C.J. and Rudall, P.J. (1999) Calcium Oxalate Crystals in Monocotyledons: A Review of Their Structure and Systematics. Annals of Botany, 84, 725-739. http://dx.doi.org/10.1006/anbo.1999.0975

[34] Horner, H.T., Wanke, S. and Samain, M.S. (2009) Evolution and Systematic Value of Leaf Crystal Macropatterns in the Genus Peperomia (Piperaceae). International Journal of Plant Sciences, 170, 343-354. http://dx.doi.org/10.1086/596338

[35] Passos, J.L., Meira, R.M. and Barbosa, L.C.A. (2009) Foliar Anatomy of the Species Lantana camara and L. radula (Verbenaceae). Planta Daninha, Viçosa-MG, 27, 689-700.

[36] Lersten, N.R. and Horner, H.T. (2000) Calcium Oxalate Crystal Types and Trends in Their Distribution Patterns in Leaves of Prunus (Rosaceae: Prunoideae). Plant Systematics and Evolution, 224, 83-96. http://dx.doi.org/10.1007/BF00985267

[37] Lersten, N.R. and Horner, H.T. (2009) Crystal Diversity and Macropatterns in Leaves of Oleaceae. Plant Systematics and Evolution, 282, 87-102. http://dx.doi.org/10.1007/s00606-009-0209-1

[38] Lersten, N.R. and Horner, H.T. (2011) Unique Calcium Oxalate “Duplex” and “Concretion” Idioblasts in Leaves of Tribe Naucleeae (Rubiaceae). American Journal of Botany, 98, 1-11. http://dx.doi.org/10.3732/ajb.1000247

[39] Metcalfe, C.R. and Chalk, L. (1979) Anatomy of the Dicotyledons, Vol. 1: Systematic Anatomy of the Leaf and Stem. Oxford University Press, New York. 
Scientific Research Publishing (SCIRP) is one of the largest Open Access journal publishers. It is currently publishing more than 200 open access, online, peer-reviewed journals covering a wide range of academic disciplines. SCIRP serves the worldwide academic communities and contributes to the progress and application of science with its publication.

Other selected journals from SCIRP are listed as below. Submit your manuscript to us via either submit@scirp.org or Online Submission Portal.
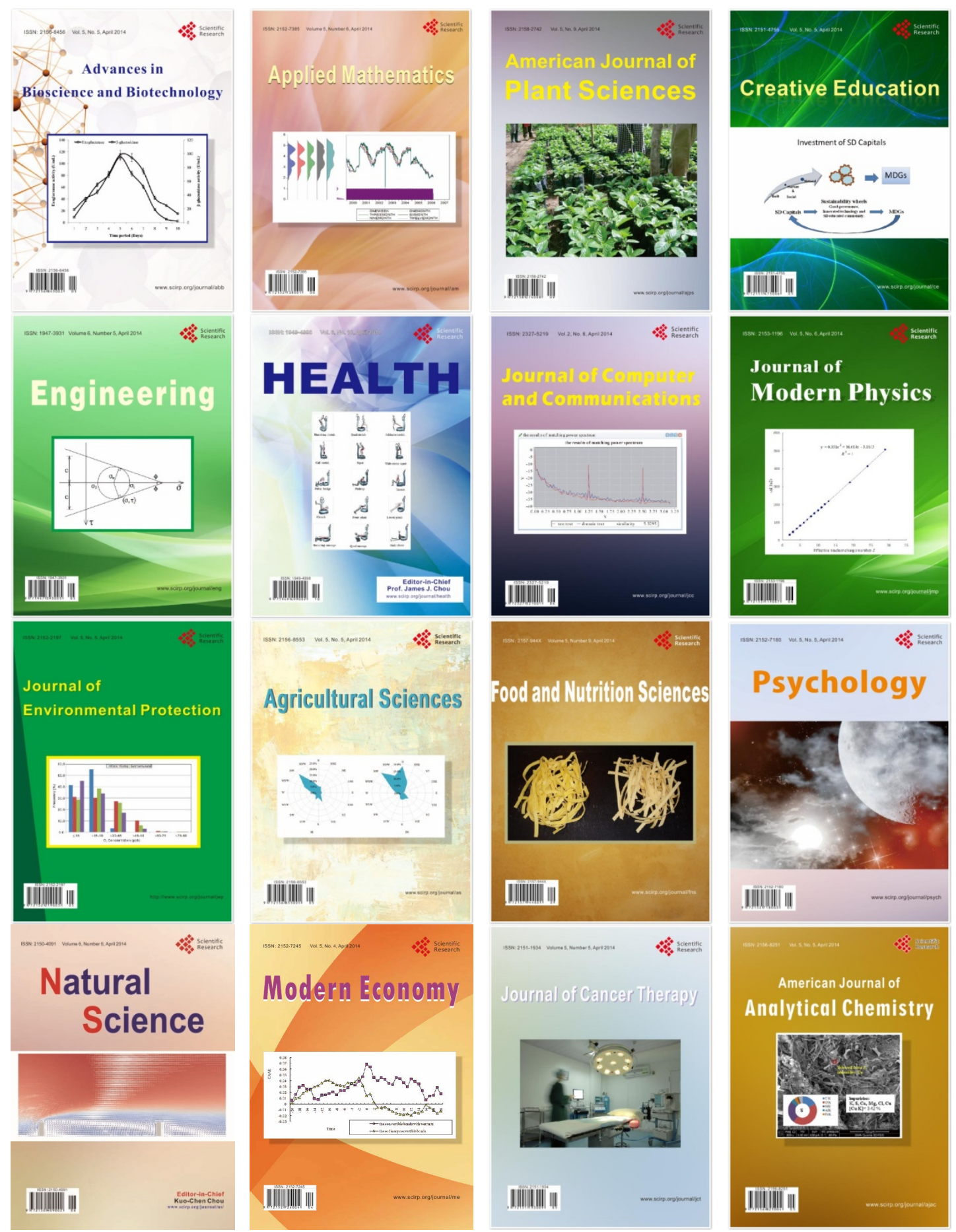